\title{
New species in the marine diatom genus Olifantiella (Bacillariophyta, Biraphidineae) from Rodrigues Island (Western Indian Ocean)
}

\author{
Catherine RiauX-GobIN ${ }^{* 1} \&$ Adil Yousif AL-HANDAL ${ }^{2}$ \\ ${ }^{1}$ USR 3278 CNRS-EPHE, CRIOBE-Université de Perpignan, FR-66860, France; *Corresponding author e-mail: \\ catherine.gobin@univ-perp.fr \\ ${ }^{2}$ Göteborgs Universitet, Institutionen för Marin Ekologi, Box 461, SE-405 30 Göteborg, Sweden \\ (present address: Dept. of Marine Biology, Marine Science Centre, Basra, Iraq)
}

\begin{abstract}
Olifantiella RiauX-GoBin et CompÈre (Bacillariophyta, Biraphidineae), a monospecific diatom genus from coral reef environments in Réunion Island (Western Indian Ocean), was collected from Rodrigues Island (easterly island of the Mascarene archipelago) in 2007. Several taxa with the external characteristics of Olifantiella were observed in shallow lagoon sediments. The external opening connected to the internal process is easily identified in each taxon. The processes are on the same or opposite side of the frustule, depending on the taxon. Several taxa are present: 1) Olifantiella $\mathrm{cf}$. mascarenica RIAUX-GoBIN et CoMPÈRE, 2) O. rodriguensis sp. nov., with an elongate shape and a double buciniportula, 3) $O$. gorandiana sp. nov., with a naviculoid shape and a complex buciniportula composed of two flattened tubes, that do not protrude, flanked by two small satellites, and 4) $O$. pilosella sp. nov., O. paucistriata sp. nov. and O. pseudobiremis sp. nov., which are only described from external views. The scarcity and minute size of the taxa necessitated the use of scanning electron microscopy (SEM) to examine and distinguish them accurately. Some LM observations were made when possible. During previous tropical marine surveys, the genus Olifantiella may have been overlooked or misidentified, due to its small size, fragile frustules, and often naviculoid shape. We discuss the morphological diversity of the genus, e.g. the frustule and buciniportula shape and structure, and propose a formal emended description of the genus Olifantiella.
\end{abstract}

Key words: coral reef diatom, Olifantiella, buciniportula, Rodrigues Island, Indian Ocean

\section{Introduction}

During a survey of benthic diatoms associated with coral reefs off Réunion Island (COSADIM program 2005, Coral sand diatoms off Mascarenes), a small-sized biraphid pennate diatom showing surprising characteristics was discovered and named Olifantiella (RIAUX-GoBIN $\&$ COMPÈre 2009). The name of the new genus referred to the internal striking, horn-shaped ('Olifant') tubular process (buciniportula). A single species was found: O. mascarenica RIAUXGobIn et COMPÈre. The distinctive features of the genus were discussed and compared with those of Luticola MANN ex Round et al., Diadesmis KÜTZING, Labellicula VAN DE VIJVER et LANGEBertalot, Brachysira KützING, Neidium Pfitzer and Nupela VyVERMAN et COMPÈRE.

The main characteristics of the genus Olifantiella, as described for the generitype $O$. mascarenica, are 1) parallel striae, slightly radiate on apices, composed of one transapically elongate areola [or macroareola, following the definition proposed by BuKHTIYAROVA (2006) for Karayevia], with a finely perforated hymen, 2) marginal, elevated ridge, 3) hymen of the macroareolae uninterrupted under the elevated ridge, 3) central pores bent away from the external opening of the process, 4) terminal raphe slit simple and very slightly bent, 5) a well-identifiable funnel-like opening, on both valves, giving access to an internal process, 6) raised internal tubular process, buciniportula, ending in a round bell-mouth, 7) several girdle bands with rows of puncta, 8) strict marine habitat.

Except for its unique internal process (see below) and several morphological dissimilarities, Olifantiella shows close similarities with Labellicula, also a monospecific genus, discovered on soils in Crozet Archipelago (VAN DE VIJVER et al. 2005). According to the original description by VAN DE VIJVER et al. (2005), Labellicula has 1) "T-shaped terminal raphe endings, as in Brachysira", 2) central raphe 
endings "unilaterally deflected in the direction of the stigma", 3) very small, slightly domed and transapically elongated internal stigmata, as in Fistulifera LANGE-Bertalot, 4) external pore of the stigma "not always visible", 5) striae split in two parts by a marginal longitudinal hyaline bar, and 6) terrestrial habitat subjected to sea spray.

About the morphology and ecology of Labellicula, it can be noticed from the original illustrations (ibid., Fig. 15), that the terminal raphe endings are not really $\mathrm{T}$-shaped, but relatively similar to that of Olifantiella. Idem about the external opening of the process (ibid., Fig. 14). The diatom community in which Labellicula was found is typical of elevated salinities. Real differences between the two genera are: 1) the internal process (tubular in Olifantiella), 2 ) the external central raphe ending curvature (opposite to the external opening of the process in Olifantiella) and 3) the marginal ridge crossing over the striae on the valve of Olifantiella. Other features, such as the structure of the hymenes and copulae, show high similarities between the two genera.

In 2007 we investigated Rodrigues Island (far-eastern island of Mascarenes) in order to enlarge our survey of the benthic marine diatoms of the archipelago. Several taxa with the main external characteristics of the genus Olifantiella were found and are described herein as new taxa. Two of the taxa possess the internal features of the genus, while the other three, which are extremely rare, were only observed externally.

In the present paper we describe new species of Olifantiella and propose a formal emended generic description taking into account the features of the new taxa.

\section{Material and Methods}

Several sites were sampled from marine to brackish sites in the vicinity of the fringing reefs off Rodrigues during the period June 03-18, 2007, and particularly several intertidal coral sands: at Port Mathurin and Anse-aux-Anglais (19०40'60 S; $63^{\circ} 25^{\prime} \mathrm{E}$, close to Port Mathurin, capital of Rodrigues), Hermitage Island $\left(19^{\circ} 45^{\prime} \mathrm{S} ; 63^{\circ} 26^{\prime} .5 \mathrm{E}\right)$ and Île au Chat $\left(19^{\circ} 46^{\prime} .5 \mathrm{~S}\right.$; $\left.63^{\circ} 25^{\prime} .5 \mathrm{E}\right)$, isolated islands with low anthropogenic influence. Nutrient concentrations at the Rodrigues sites were compared to those in Réunion, and are discussed elsewhere with reference to possible anthropogenic influence (RIAUX-Gobin et al. 2011).

Intertidal samples were obtained by scraping the coral sediment surface, the decaying mats and the undetermined turf and debris when present. Samples were formalin-preserved (10\% final dilution). For scanning electronic microscopy (SEM), preserved field samples were collected on $1 \mu \mathrm{m}$ Nuclepore filters, followed by 2 rinses with deionised water (milliQ) to remove salts. The filters were air-dried and mounted in toto onto aluminum stubs before coating with gold palladium alloy (EMSCOP SC 500 apparatus), and examined with a Hitachi S-4500 SEM operated at 10 $\mathrm{kV}$ (in 2007-2009) or $8 \mathrm{kV}$ (in 2010) (University of Perpignan, Via Domitia, France). For light microscopy (LM), Naphrax ${ }^{\circledR}$ mounted slides were examined under a Zeiss Axio Imager 2 (Marine Science Centre, University of Basra) and images taken by Canon Powershot 10 camera.

The characteristics of the small-sized generitype were hardly discernible in LM although it was relatively abundant (RIAUX-Gobin \& Compère 2009). The taxa presented in this study were rare to extremely rare and so only some LM pictures possibly matching several new taxa are given. Observations by SEM were used to describe their morphology. Although it is difficult to durably preserve specimens on the stubs used for examination in SEM, they are referenced and kept in an air dry container. According to Art. 37.5 of the International Code of Botanical Nomenclature (McNEIL et al. 2006), we designate as holotype of the new species, the stub with the specimens which best show the features diagnostic of the new taxa. We designate as paratypes the LM slides made from the samples in which a new taxon was observed and described, even if, due to the small size of these diatoms, their presence on the slides is not always obvious.

For the morphometry of each species, the range, average and standard deviation (SD) are provided. We revise the morphometric data of Olifantiella mascarenica RiauX-Gobin et Compère (Table 1) described from the Réunion material (RIAUX-GoBIN \& COMPÈRE 2009). The terminology follows AnONyMOus (1975), Ross et al. (1979) and Round et al. (1990).

\section{Description of Rodrigues taxa}

Olifantiella cf. mascarenica RIAUX-GoBIN et CoMPÈre [(?)Fig. 1, LM; Figs 4-10, SEM]

Features $(\mathrm{n}=20): 6-15(12 \pm 1.8) \mu \mathrm{m}$ long; $2-3(3 \pm$ $0.2) \mu \mathrm{m}$ wide

Stria density: $31-44(36 \pm 6)$ striae in $10 \mu \mathrm{m}$

L/W (length/width): $4.5+0.8$

Description and remarks: Olifantiella cf. mascarenica from Rodrigues closely resembles the generitype from Réunion, but is slightly larger (on average 12 vs $9 \mu \mathrm{m}$ long respectively), with higher stria density (on average 36 vs 32 striae 


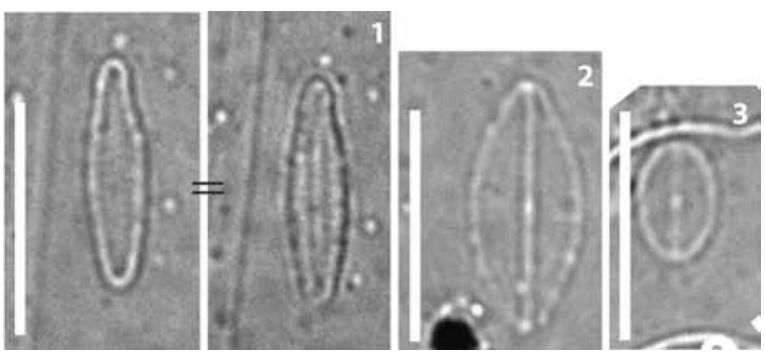

Figs 1-3. LM images: (1) (?)Olifantiella cf. mascarenica, at two different foci; $(2,3)$ (?)Olifantiella gorandiana sp. nov. Scale bars $10 \mu \mathrm{m}$

in $10 \mu \mathrm{m}$ respectively). The internal process or buciniportula is horn-shaped, av. $0.3 \mu \mathrm{m}$ high, similar to that of the type, but in the Rodrigues samples it is always closed by a plug (Figs 8-10). This plug, resembling the lid closing the trap of the macrophyte Nepenthes, has a symmetric ornamentation composed of two lateral curved grooves (Figs 8-10), corresponding to the semicircular opening of the plug. In Rodrigues, all specimens showing both valves have the two buciniportulae on the same side of the frustule (e.g. Figs 4, 6, arrows), while in Réunion they are always on the opposite side: this particularity has to be confirmed after checking more specimens. Presence of a siliceous nodule in between the central raphe endings, and slightly raised helictoglossae, as in the type.

Habitat: Port Mathurin beach, coral sediments, relatively rare.

Olifantiella rodriguensis RIAUX-GobIN sp. nov. (Figs 11-22, SEM)

Features $(\mathrm{n}=21)$ : $11-14(13 \pm 1) \mu \mathrm{m}$ long; $2-3(2$ $\pm 0.3) \mu \mathrm{m}$ wide

Stria density: $35-46(38 \pm 4)$ striae in $10 \mu \mathrm{m}$ L/W: $5 \pm 0.8$

Descriptio: Frustula isovalvata et biraphidea, solitaria. Valvae valde oblongae, aciculariforme, rostratae et subcapitatae, apicibus rotundatis, 11-14 $\mu$ m longae, 2-3 $\mu$ m latae; c. 38 striae in $10 \mu \mathrm{m}, \mathrm{SD} 4$.

Similis cum typo generis, sed cum elongatioribus valvis et duabus buciniportulis per valvam. Externum foramen unum, sed processus in duabus partibus internale fissus. Buciniportulae leniter breviores eis typi generis, et axiale symmetricae.

Description: very similar to the generitype, but with an oblong linear valve with capitate apices (Figs 11-13). Striae slightly more radiate than in the generitype, with higher stria density (on average 38 vs 32 striae in $10 \mu \mathrm{m}$ respectively). Buciniportula complex, with two raised tubular processes on each valve, slightly shorter than in the generitype and always plugged (Figs 22-22). All specimens showing both valves have the two buciniportulae on the opposite side of the frustule (cf. Fig. 13). Externally, the opening of the process is unique, transapically oblong, distinctly split in two parts in a deeper layer (Fig. 16, arrows). Two shortened striae are present near the valve margin on the side of the external opening of the buciniportulae (Figs 16-18). Presence of a nodule in between the central raphe endings, helictoglossae slightly raised (Fig. 15).

Remark: the paired tubular process, oblong cell shape and stria density, support the creation on a new species.

Habitat: present but rare, only found on Rodrigues (Port Mathurin beach).

Holotype: stub 2 (13 11 09) from sample "Port Mathurin 2": Fig. 12, original picture (SEM 201109-6) in Collection C. RIAUX-GobIN (USR 3278 CNRS-EPHE, CRIOBE-Université de Perpignan, France).

Type locality: Port Mathurin marine coastal area (Rodrigues Island).

Isotypes: from sample "Port Mathurin 2", sampled in June 2007, Slide BM 101461 deposited in the National History Museum (London, U.K.), slide ZU7/42 in the Hustedt Collection (Bremerhaven, Germany), slide "ALH TRO GOT 121" in Collection A.Y. AL-Handal (Göteborgs Universitet, SE-405 30 Göteborg, Sweden) and slide ROD1 in Collection C. RIAUX-GobIN.

Etymology: the epithet refers to Rodrigues Island, where the species was discovered.

Olifantiella gorandiana RIAUX-GobIN sp. nov. [(?)Figs 2, 3, LM; Figs 23-45, SEM]

Features ( $\mathrm{n}=19): 5-8(6 \pm 0.5) \mu \mathrm{m}$ long; $1-3(2 \pm 0.5)$ $\mu \mathrm{m}$ wide

Stria density: $51-69(59 \pm 8)$ striae in $10 \mu \mathrm{m}$

$\mathrm{L} / \mathrm{W}: 2.8 \pm 0.5$

Descriptio: Frustula isovalvata et biraphidea, solitaria. Valvae parvae, naviculiformes ad leniter subrostratae, apicibus rotundatis. 5-8 $\mu \mathrm{m}$ longae, 1-3 $\mu \mathrm{m}$ latae; c. 59 striae in $10 \mu \mathrm{m}, S D 8$.

Externa structura: valva leniter axiale concava; uniseriatae striae radiantes ad subparallelae, externe per totam longitudinem apertae et interne granulato hymenio clausae. Foramen processus interni subquadrangulare praesens unilateraliter, juxta marginalem, ad extremitatem striarum duarum 

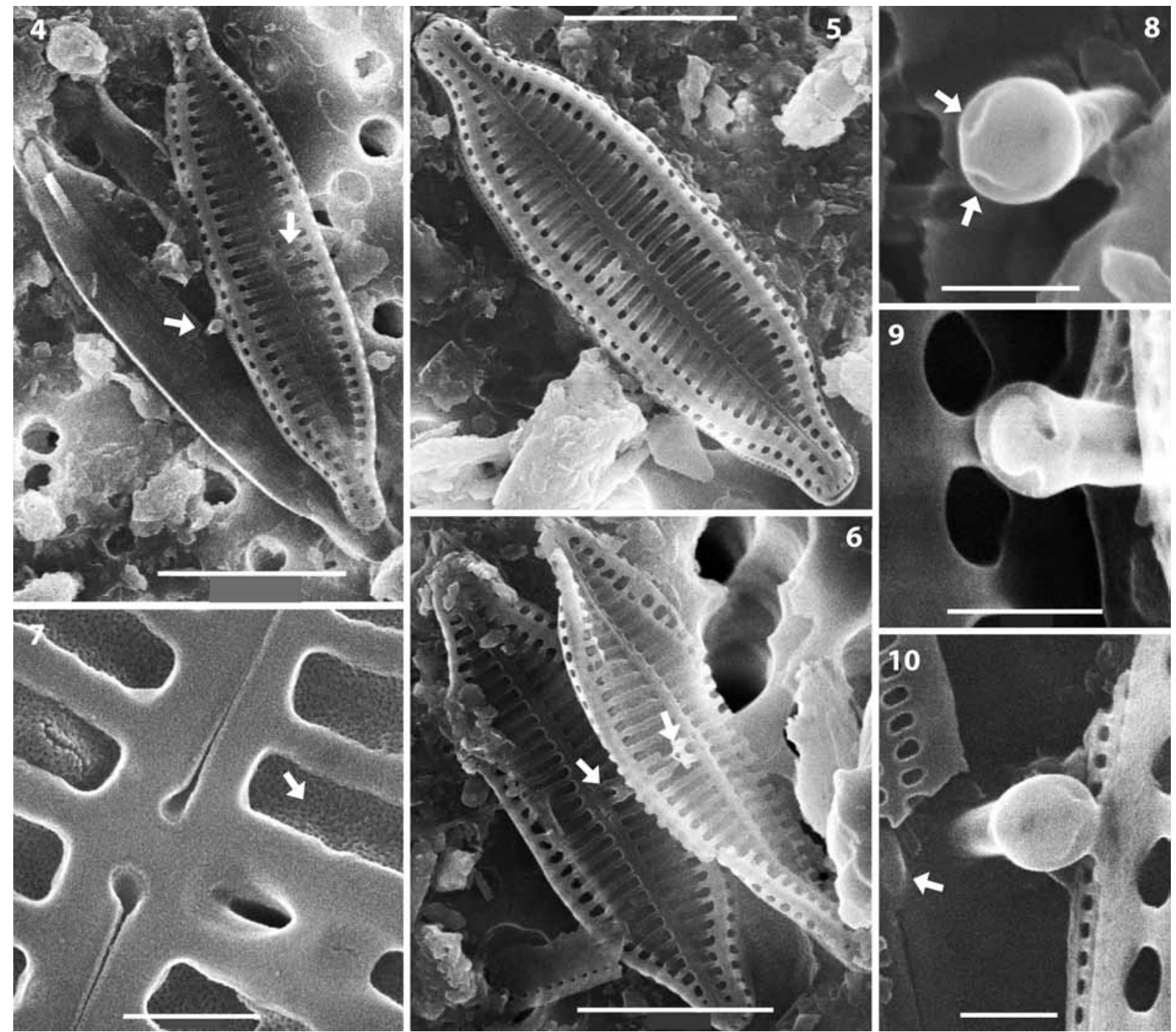

Figs 4-10. Olifantiella cf. mascarenica, (SEM): $(4,7)$ open frustules showing the buciniportula and the external process opening, on the same side of the frustule (arrows); (5) external view of the valve; (7) central area, with raphe endings close to each other, rounded, and deflected away from the process opening. Note the finely perforated macroareola hymen (arrow) and interstriae slightly raised. (8-10) internal trumpet-like process or buciniportula, with a plug showing two symmetric grooves (Fig. 8, arrows). Note the nodule between the raphe endings, facing the base of the buciniportula (Fig. 10, arrow). Scale bars $4 \mu \mathrm{m}$ (Fig. 4), $3 \mu \mathrm{m}$ (Figs 5, 6), $0.4 \mu \mathrm{m}$ (Fig. 7), $0.3 \mu \mathrm{m}$ (Figs 8-10).

centralium. Crista longitudinalis ad angulum inter limbum et frontem posita. Elongata foramina in apicibus. Intercostae elevatae. Area axialis anguste linearis. Raphe recta filiformis; pori centrales approximati, simpliciter dilatati et leniter deflecti ab processus foramine; pori externi terminales simpliciter dilatati et leniter deflecti. Plures copulae cum duabus seriebus punctorum ordinatis aut in lineis oppositis aut quincuncialibus.

Interna structura: raphe posita in eminentia et ad apices in humili helictoglossa terminans; centrales pori simplices et rotundati cum media rotunda prominentia inter eos. Parvi loculi praesentes in apicibus, congruentes cum externis elongatis foraminibus. Interne processus cum duabus tubaeformibus structuris, non erectis sed complanatis et contra parietem valvae positis, cum duobus parvulis satelliticis comitatus. Externum foramen marginale, unilateraliter praesens.

Description: small-sized naviculoid cell, with round to sub-rostrate apices (Figs 23, 26). Striae composed of macroareolae closed by a finely perforated hymen, internally domed. Complex internal buciniportula composed of two flattened tubes, not protruding, running from the valve margin toward the central nodule (e.g. Fig. 34), ending in fans and flanked by two small satellites (Figs 34-35, arrows); the two major tubes can be seen through the wall of the cell (Figs 37, 39, 40, arrows), their apertures (Fig. 41, arrows) and prolongation on the frustule (Fig. 38, arrows) 

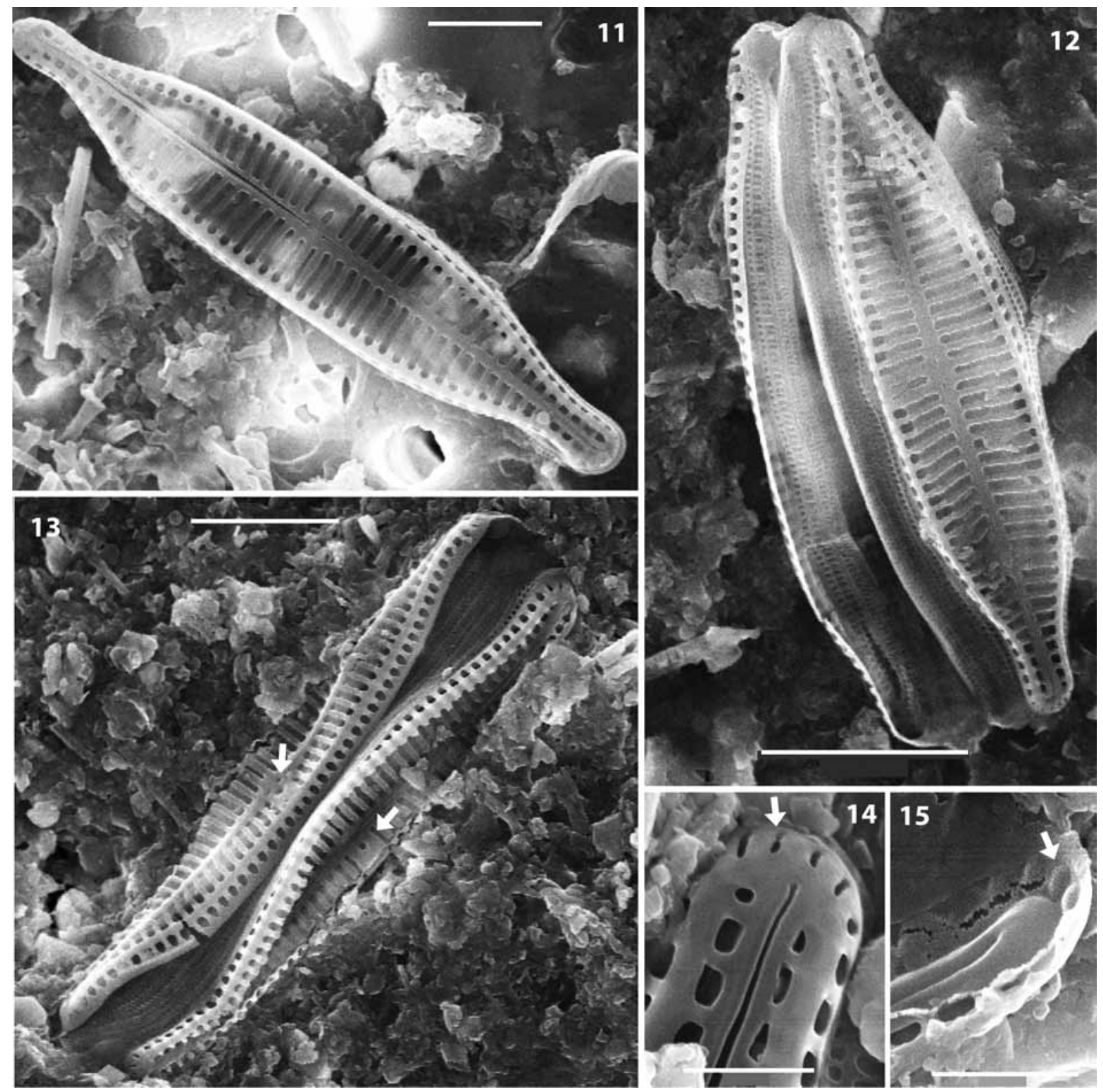

Figs 11-15. Olifantiella rodriguensis sp. nov., (SEM): (11-13) external views of the valve, with process openings on opposite sides of the frustule (Fig. 13). Note the process opening and two shortened striae. $(14,15)$ external and internal views of the valve apex, with apical slits (Fig. 14) and internal domed hymenes (Fig. 15, arrow), slightly raised helictoglossa (Fig. 15). Scale bars $3 \mu \mathrm{m}$ (Figs 12, 13), $2 \mu \mathrm{m}$ (Fig. 11), $0.7 \mu \mathrm{m}$ (Figs 14, 15).

can be observed on corroded and broken valves. All specimens showing both valves had the two buciniportulae on same side of the frustule (e.g. Fig. 25). The external opening of the process is trapezoidal (Figs 32, 33) to quadrangular (Fig. 39) or triangular (Fig. 29); located near the valve margin, with a deeper median plain floor, splitting the opening into four smaller ones (one at each corner of the opening, Fig. 33, white arrows). On the side of the external opening of the buciniportula, two striae are lacking and two are shortened near the valve margin (Fig. 29, arrows). Striae equidistant. Several large and open girdle bands (up to four, Fig. 43, white frames and arrows), with two rows of more or less elongated puncta closed by a finely perforated velum (very similar to the hymen of the macroareolae, Fig. 45, arrow). Note that one copula may lack puncta (Fig. 44, arrows). A ridge is situated at the junction of the valve face and the mantle, crossing over the stria hymenes (as illustrated in Figs 30-31, arrows); this ridge is less elevated than in O. mascarenica. Small irregularities are observed along the interstriae (Fig. 31), as in the generitype (RIaUX-Gobin \& COMPÈre 2009, Fig. 9). Four short slits present on apices (Fig. 26). Helictoglossae very slightly 


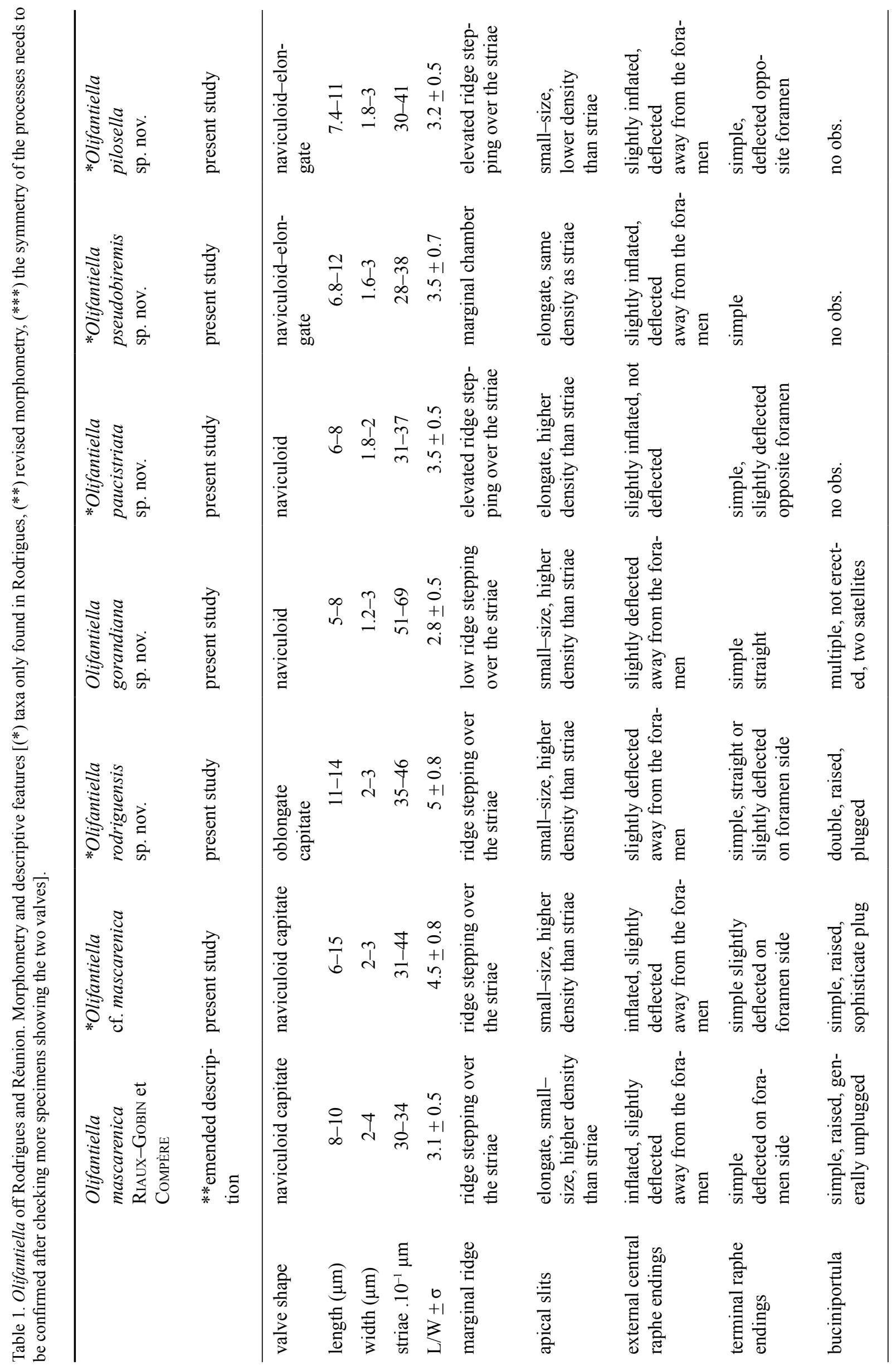




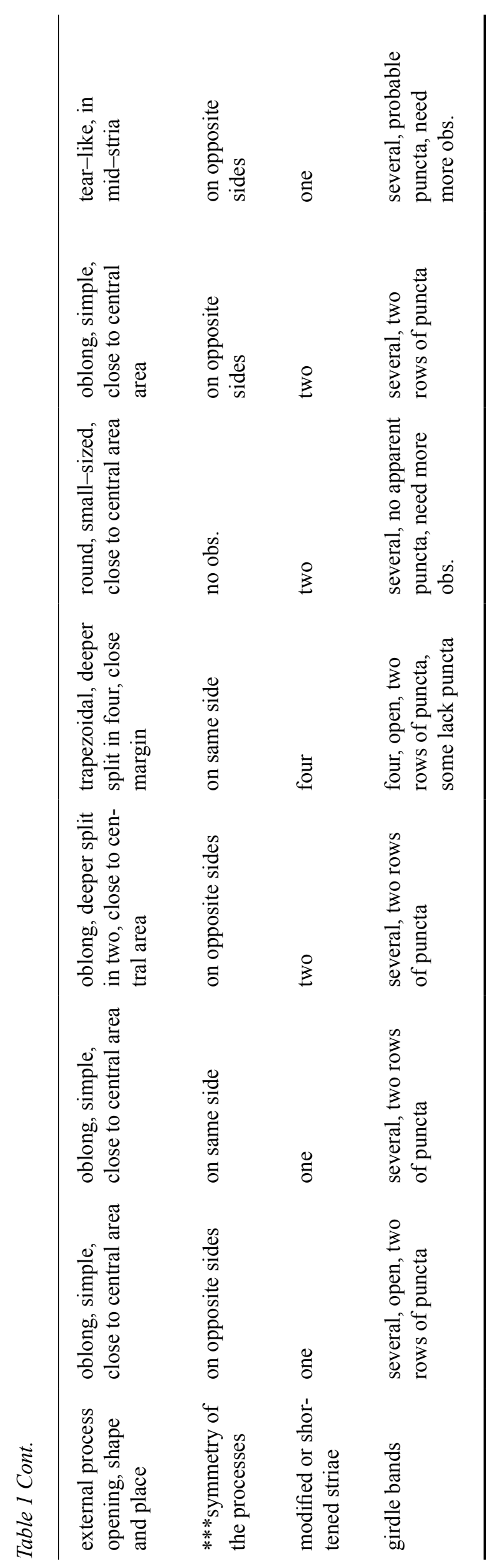

raised (Fig. 36, arrow). Internally, a discrete and oblong nodule is present in between the raphe central endings (Fig. 34).

Remarks: the internal process of $O$. gorandiana is complex and differs from a simple stigma or group of stigmata. This process is composed of tubular structures and may be named buciniportula, even if not protruding as in the generitype. Contrarily to the other taxa described here, the buciniportula is located in the margin of the valve, at the junction of the valve face and the mantle. Furthermore the shape of the valve is naviculoid, with a very low $\mathrm{L} / \mathrm{W}(2.8 \pm 0.5$ vs $4.5 \pm 0.8$ in $O$. cf. mascarenica).

Habitat: found in Rodrigues, relatively rare. Only three specimens of the entire buciniportula were observed and photographed.

Holotype: stub 5 (04 11 09) from sample "Port Mathurin 2": Fig. 22, original picture (SEM 061109-34) in Collection C. RiauX-GobIN.

Type locality: Port Mathurin marine coastal area (Rodrigues Island).

Isotypes: see Olifantiella rodriguensis (slides BM 101461, ZU7/42, ALH TRO GOT 121, ROD1).

Etymology: dedicated to DiMITRI GORAND (C2M, Université de Perpignan Via Domitia) for his valuable SEM assistance on Kerguelen and Mascarene studies during numerous years.

Olifantiella paucistriata RIAUX-GobIN sp. nov. (Figs 46-58, SEM)

Features $(\mathrm{n}=5)$ : $5.6-8(7 \pm 1) \mu \mathrm{m}$ long; $1.8-2(2 \pm 0.1)$ $\mu \mathrm{m}$ wide

Stria density: $30.5-37(33 \pm 2.9)$ striae in $10 \mu \mathrm{m}$ $\mathrm{L} / \mathrm{W}: 3.5 \pm 0.5$

Descriptio: Frustula isovalvata et biraphidea, solitaria. Valvae naviculiformes, apicibus rotundatis. 5.6-8 $\mu \mathrm{m}$ longae, $1.8-2 \mu \mathrm{m}$ latae ; c. 33 striae in $10 \mu \mathrm{m}, \mathrm{SD}$ 2.9 .

Externa structura: valva leniter axialis concava; uniseriatae striae radiantes ad subparallelae, externe per totam longitudinem apertae et granulato hymenio clausae. Foramen processus interni rotundatum et parvulum, praesens unilateraliter, juxta porum centralem, ad extremitatem striarum duarum centralum. Crista longitudinalis valde elevata, ad angulum inter limbum et frontem posita. Foramina in apicibus. Intercostae elevatae. Area axialis anguste linearis. Raphe recta; pori centrales approximati, simpliciter dilatati et leniter deflecti ab processus foramine; pori externi terminales simpliciter dilatati et leniter deflecti.

Interna structura: non observata. 

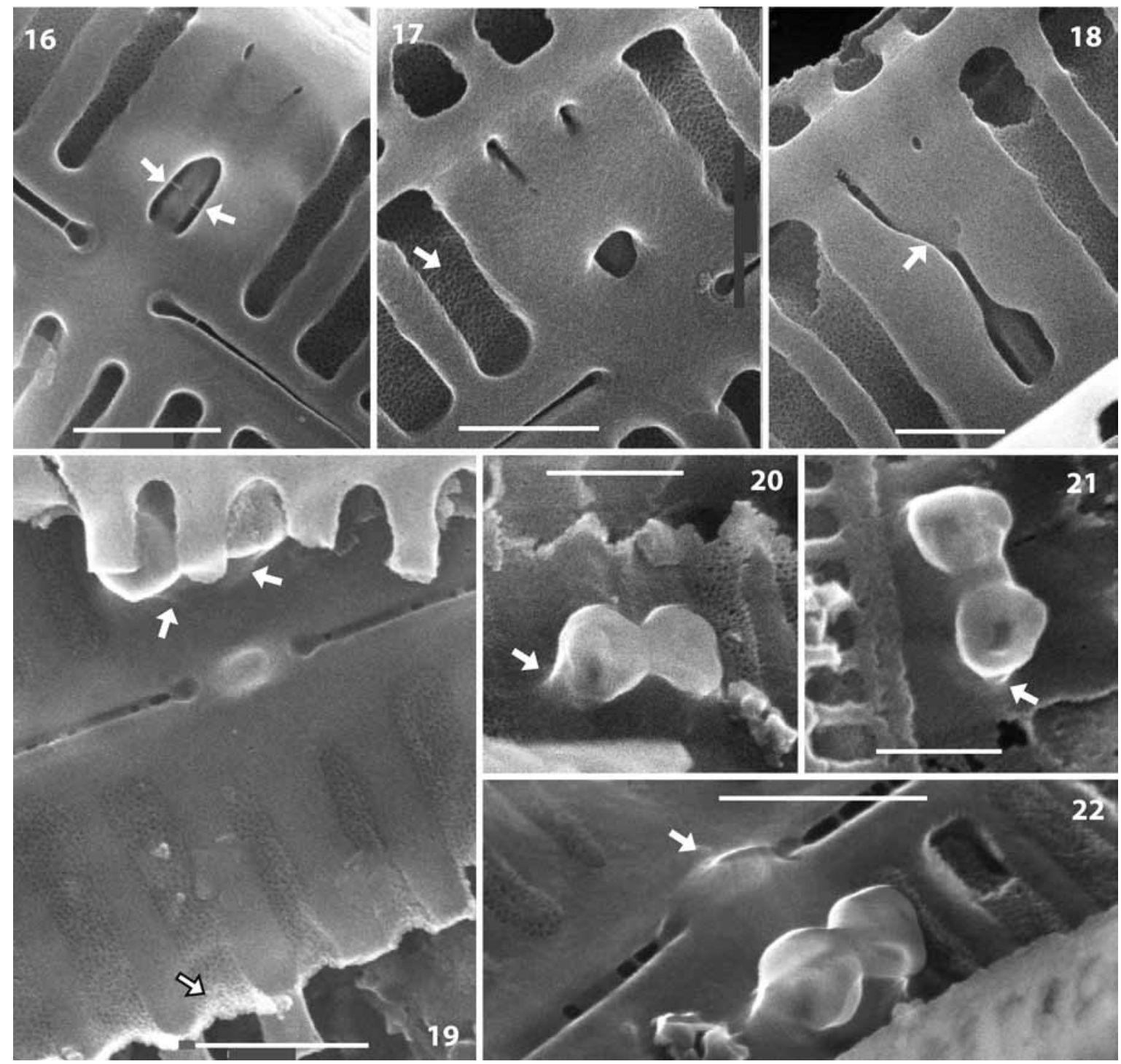

Figs 16-22. Olifantiella rodriguensis sp. nov., (SEM): (13-18) details of the buciniportula, with an opening split in two parts (Fig. 16, arrows) facing two shortened striae (Fig. 17). Connection between the shortened-modified striae and the process opening (Fig. 18, arrow). (19-22) internal views of the double buciniportula, with erected tubular basal part (Figs 19-21, white arrows), nodule between the central raphe endings (Fig. 22), striae continue under the marginal ridge (Fig. 19, framed arrow). Scale bars $0.5 \mu \mathrm{m}$ (Figs 16, 19, 22), $0.3 \mu \mathrm{m}$ (Figs 17, 18, 20, 21).

Description: small-sized naviculoid frustule (Figs 47-49). Striae composed of macroareolae with a finely perforated hymen. At the junction of the valve face and the mantle a prominent, large ridge, running over the striae, and opening by large round to sub-quadrangular fenestrae (Figs $48,51,53)$. Three to five slightly elongate slits, denser than striae, are present on apices (Fig. 50). The external opening of the internal process is a small round aperture, near one of the central raphe endings (Fig. 56); it apparently elongates by an internal tube (Figs 54-55, 57, white arrows). A small depression is observed close to the other raphe ending (Figs 55-56, framed arrows). Two shortened striae are present near the valve margin on the side of the external opening of the process (Fig. 58, arrows). So far internal process not observed. Specimens showing both valves have the two buciniportulae on the opposite side of the frustule, as illustrated in Fig. 46. Striae equidistant. Girdle bands not properly observed.

Remarks: extremely rare (5 specimens observed and photographed). The external characteristics are similar to those shared by the genus Olifantiella, but with particular features: the lateral ridge is much more elevated than in the generitype and bordered by small warts numerous and well differentiated (Fig. 57). The external opening of the process is small, round and not elongate as in the generitype or in O. cf. mascarenica or O. pseudobiremis. The 

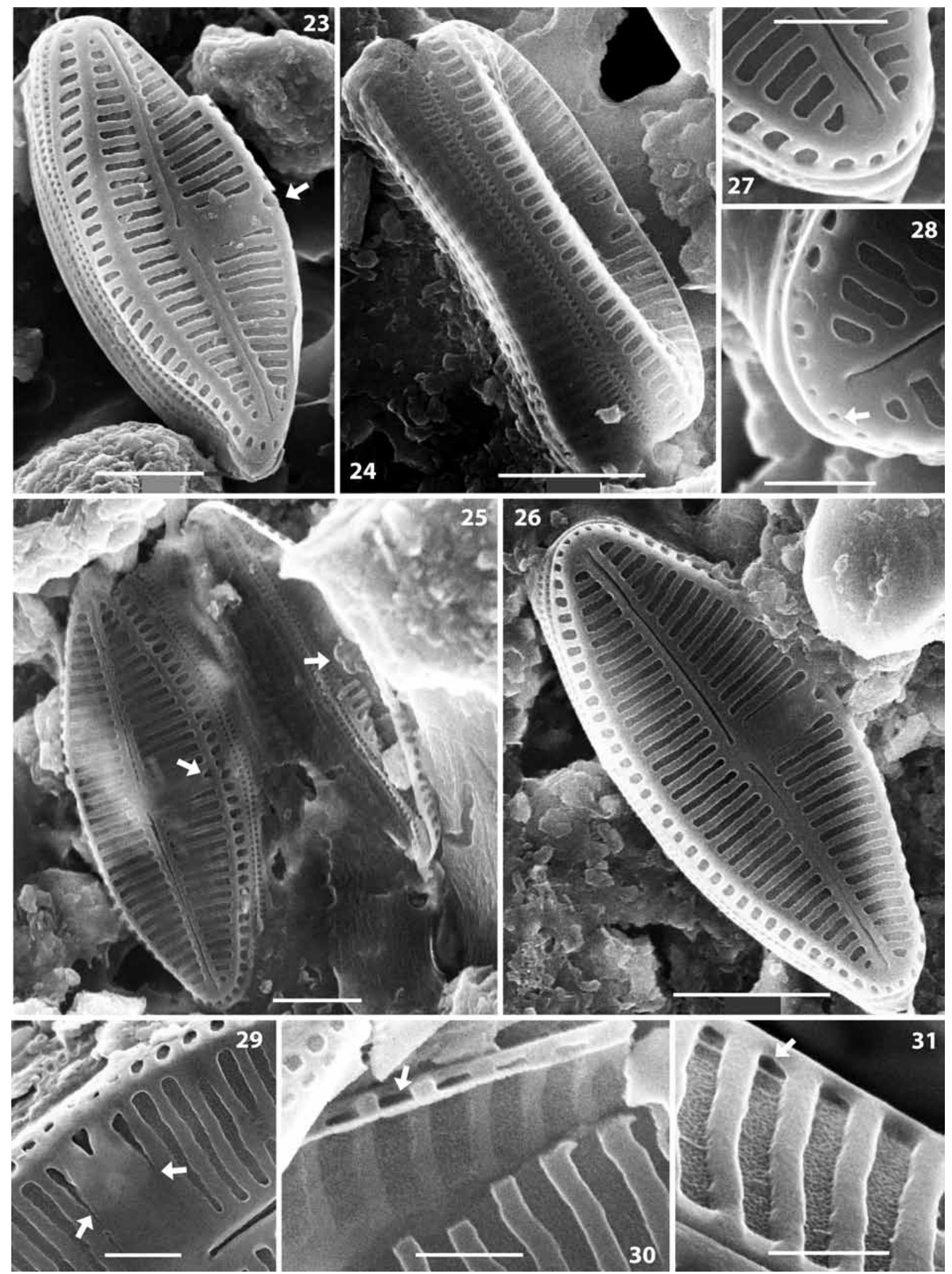

Figs 23-31. Olifantiella gorandiana sp. nov., (SEM): (25) open frustule showing the buciniportula and a process opening, on same side of the frustule; $(23,24,26)$ external views, with stria pattern (Fig. 24), marginal position of process opening and copulae with puncta; $(27,28)$ detail of the valve apex with simple raphe endings and small apical slits (Fig. 28, arrow); (29) buciniportula opening area with four modified striae (two lacking on the valve face and two shortened, arrows); $(30,31$ ) marginal low ridge stepping over the striae (arrows). Scale bars $1.5 \mu \mathrm{m}$ (Figs 24, 26), $1 \mu \mathrm{m}$ (Figs 23, 25), $0.5 \mu \mathrm{m}$ (Figs 27-28, 29), $0.3 \mu \mathrm{m}$ (Figs 30, 31). 

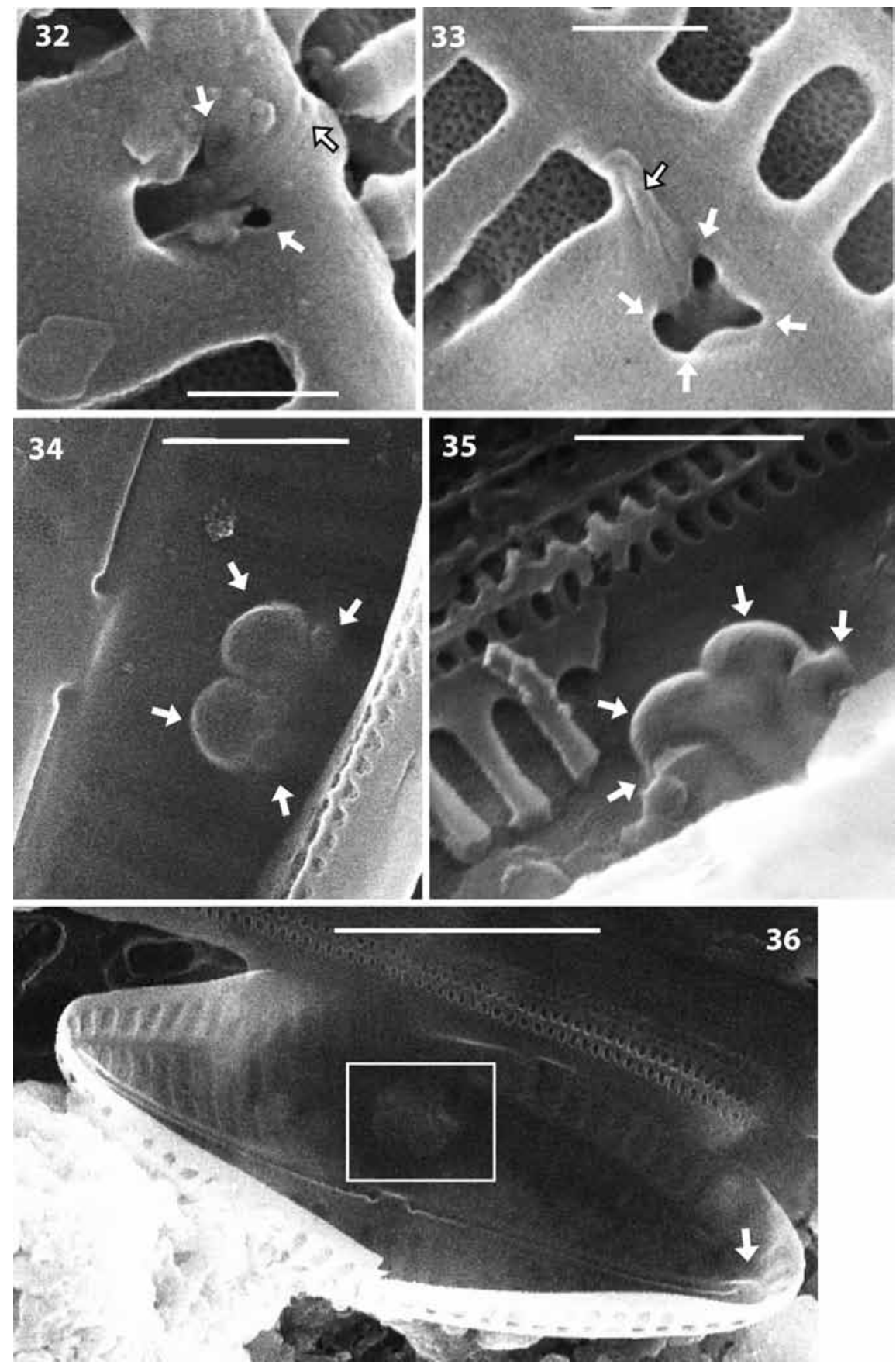

Figs 32-36. Olifantiella gorandiana sp. nov., (SEM): (32-33) marginal and trapezoidal buciniportula opening with four smaller openings on corners (Fig. 33), mucilage(?) secretion (Figs 32, 33, framed arrows); (34-35) internal multiple tubular process (buciniportula), general position on the valve (Fig. 36, white frame), tubular assemblage composed of two major structures flanked by two small satellites (Figs 34-35). Low helictoglossa (Fig. 36, arrow). Note the oblong nodule between the round central raphe endings (Fig 34). Scale bars $2 \mu \mathrm{m}$ (Fig. 36), $0.7 \mu \mathrm{m}$ (Fig. 34), $0.5 \mu \mathrm{m}$ (Fig. 35), $0.2 \mu \mathrm{m}$ (Figs. 32, 33).

presence of a small depression near the process opening, and two shortened striae on the side of this process, seems constant. Even if the number of specimens observed is low, the particular features of this taxon are unlikely to be life cycle modifications in e.g. O. mascarenica, and thus they support the creation of a new species.

Holotype: stub 1 (10 07 09) from sample "Port
Mathurin 2": Fig. 46, original picture (SEM 100709-20) in Collection C. RiaUX-GobIN.

Type locality: Port Mathurin beach (Rodrigues Island).

Isotypes: see Olifantiella rodriguensis (slides BM 101461, ZU7/42, ALH TRO GOT 121, ROD1).

Etymology: epithet refers to the low stria density of this taxon. 


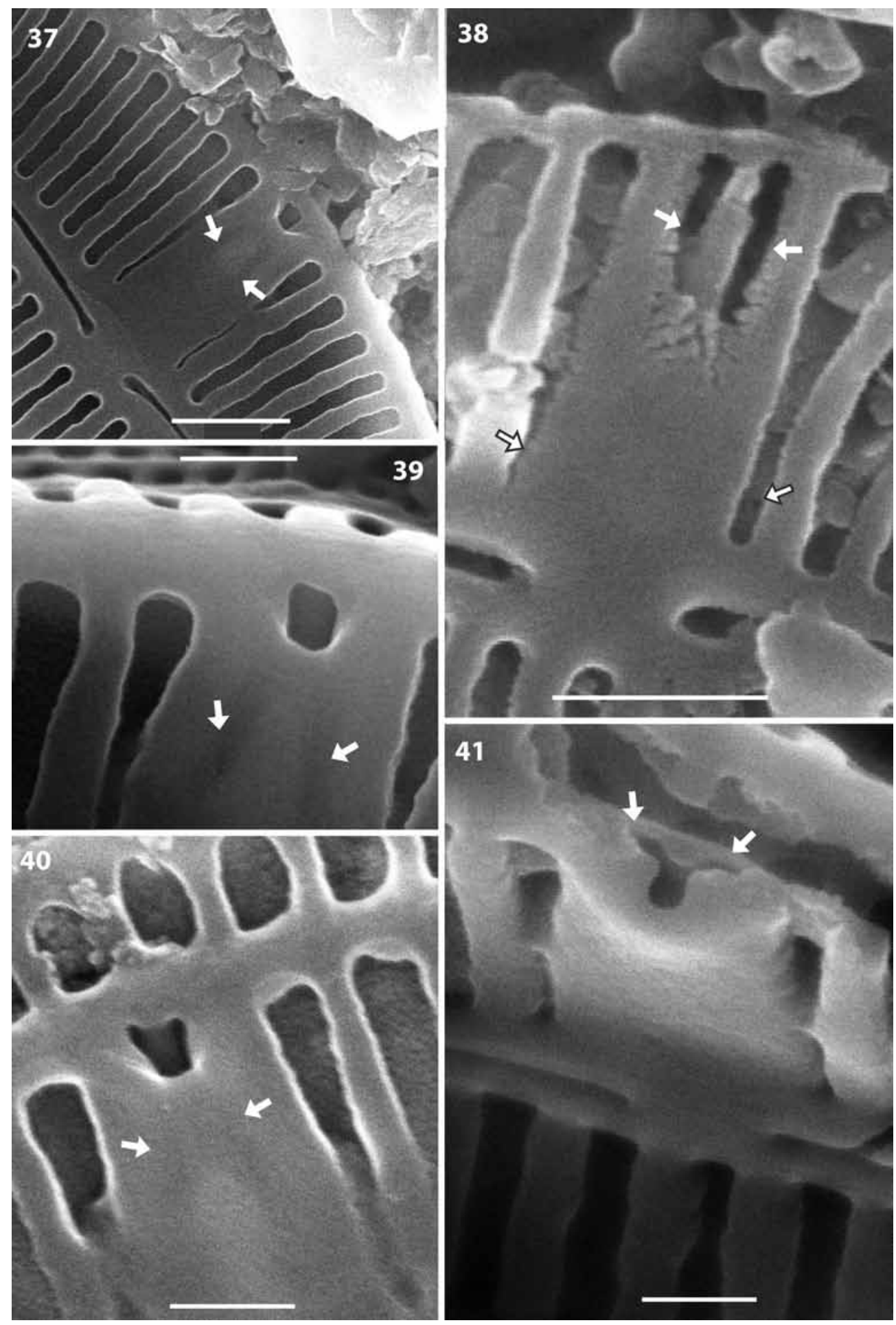

Figs 37-41. Olifantiella gorandiana sp. nov., (SEM), details of the external opening of the buciniportula: $(37,39,40)$ tubular structures seen through the valve (arrows); (38) corroded valve showing the two major tubes of the buciniportula (white arrows), and the two thinner striae (framed arrows); (41) marginal ridge broken in the region of the process opening, showing the two major tubular structures entrance (arrows). Scale bars $0.5 \mu \mathrm{m}$ (Figs 37, 38), $0.2 \mu \mathrm{m}$ (Figs 39-41).

\section{Olifantiella pilosella RIAUX-GobIN sp. nov. (Figs} 59-65, SEM)

Features $(\mathrm{n}=3): 7.4-11(8.1 \pm 2.7) \mu \mathrm{m}$ long; $1.8-3(2.6$ $\pm 0.7) \mu \mathrm{m}$ wide

Striae density: $30-41(36.3 \pm 5.8)$ striae in $10 \mu \mathrm{m}$ $\mathrm{L} / \mathrm{W}: 3.2 \pm 0.6$
Descriptio: Frustula isovalvata et biraphidea, solitaria. Valvae naviculiformes, apicibus rotundatis. 7.4-11 $\mu \mathrm{m}$ longae, 1.8-3 $\mu \mathrm{m}$ latae; c. 36.3 striae in $10 \mu \mathrm{m}$, SD 5.8.

Externa structura: valva leniter axialis concava; uniseriatae striae radiantes ad subparallelae externe 

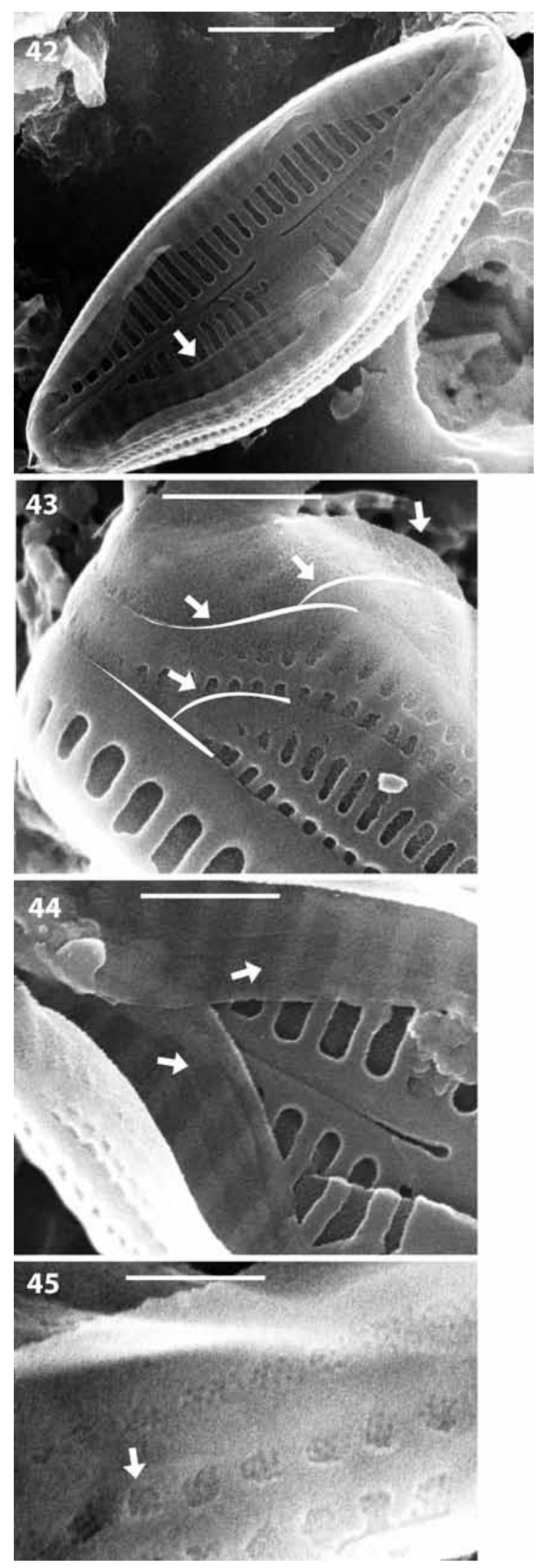

Figs 42-45. Olifantiella gorandiana sp. nov., (SEM): girdle bands, up to four, open (Fig. 43, white frames), with more or less elongate puncta, occluded by a finely perforated velum (Fig. 45, arrow). Note one copula may lack puncta (Fig. 44, arrows). Scale bars $1 \mu \mathrm{m}$ (Fig. 42), $0.5 \mu \mathrm{m}$ (Figs 43, 44), 0.2 $\mu \mathrm{m}$ (Fig. 45). per totam longitudinem apertae et granulato hymenio clausae, cum marginalibus pilis. Foramen processus interni lacrima-forme, unilateraliter, ad extremitatem striae unae centralis, juxta marginem. Unus rotundus tholus inter pori centrales positus. Crista longitudinalis elevata, ad angulum inter limbum et frontem posita. Parva et non densa foramina in apicibus. Intercostae elevatae. Area axialis anguste linearis. Raphe recta; pori centrales approximati, simpliciter dilatati et leniter deflecti ab processus foramine; pori externi terminales simpliciter dilatati et leniter deflecti.

Interna structura: non observata.

Description: small-sized elliptical to oblong frustule (Figs 59, 62). Striae composed of macroareolae, equidistant, with finely perforated hymen (Fig. 63). At the junction of the valve face and the mantle a ridge runs over the striae, and opens to the exterior by round to oblong fenestrae, bordered by long thin (vermicule-like?) spines (Fig. 61). A small fan-like appendix is protrudes from each side of the ridge, partly obliterating the fenestrae (Figs 60, 61, 65). Long thin spines are also present on the hymenes of the macroareolae (Fig. 60, arrow). Central raphe endings curved opposite to the process opening (Fig. 60). Externally, a small wart lies in between the central raphe endings (Fig. 60, arrow). Terminal raphe endings simple, slightly bent (Fig. 65). Process opening drop-like, located in between the central nodule and the valve face margin (Fig. 60). One shortened stria present near the valve margin on the side of the external opening of the process (Figs 60, 61-64). Apical slits are few and smallsized (Fig. 65). Girdle bands not fully observed.

Remarks: extremely rare, only three specimens observed, among which one broken frustule (Fig. 64) shows the two raphid valves (arrow), but unfortunately not the internal process.

Habitat: Rodrigues marine sediments. Recently found on coral sediments in Moorea (Society Archipelago, Pacific, Fig. 62), where it seems less rare than in Rodrigues, but no internal view observed so far in Moorea samples.

Holotype: stub 1 (10 07 09) from sample "Port Mathurin 2": Fig. 59, original picture (SEM 100709-34) in Collection C. RIAUX-GobIN.

Type locality: Port Mathurin beach (Rodrigues Island).

Isotypes: see Olifantiella rodriguensis (slides BM 101461, ZU7/42, ALH TRO GOT 121, ROD1).

Etymology: epithet refers to the presence of long (vermicule-like?) spines (in Latin, pili) around and on the hymen of the macroareolae. 

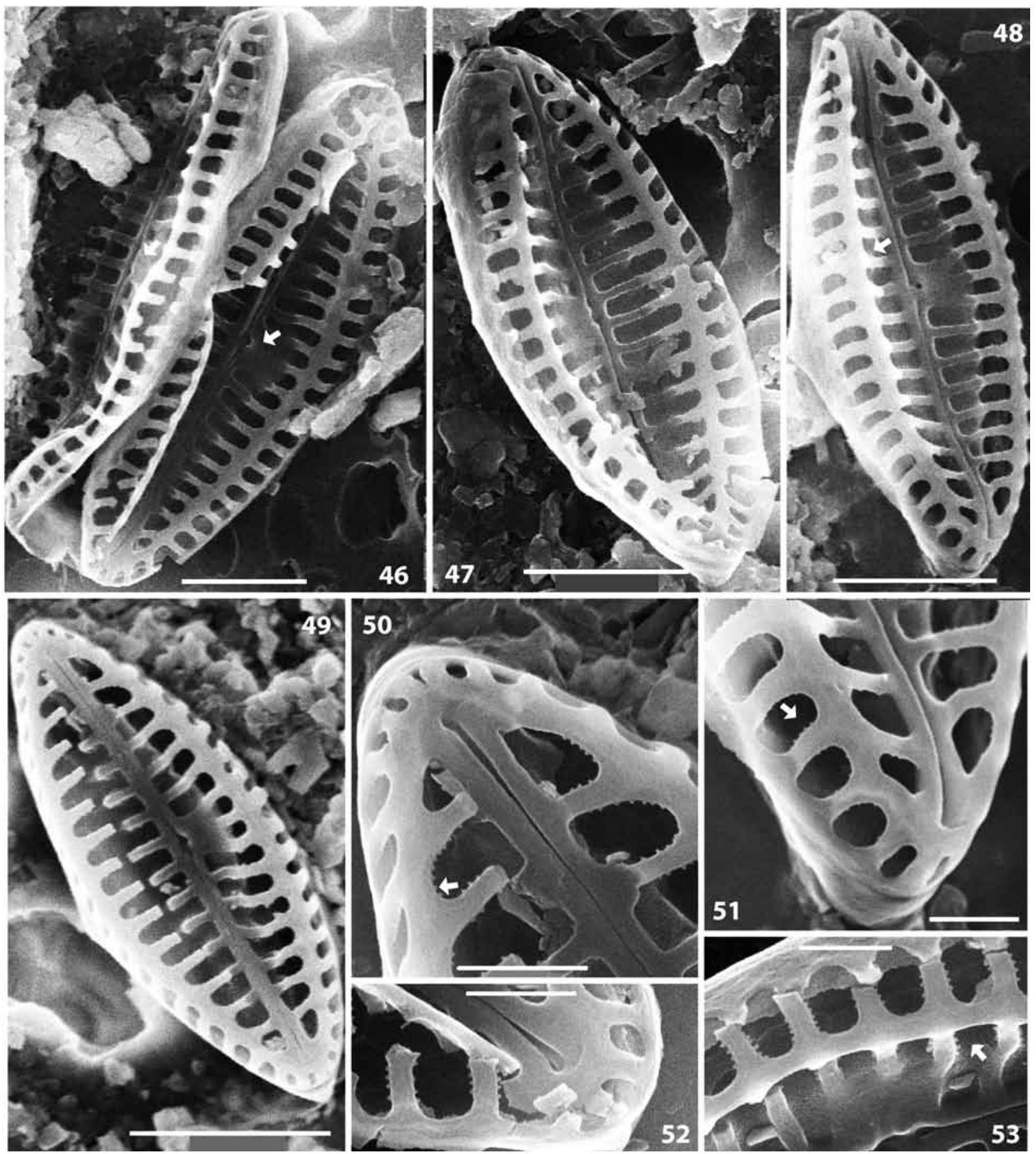

Figs 46-53. Olifantiella paucistriata sp. nov., (SEM): (46-49) external views of the valve, with a raised marginal ridge, and process openings on opposite sides of the frustule (Fig. 46); (50-53) external details of the apex with simple terminal raphe endings and small warts around the fenestrae (Figs 50-52, arrows), general view of the marginal elevated ridge (Fig. 53, arrow). Scale bars $2 \mu \mathrm{m}$ (Figs 46-49), $0.5 \mu \mathrm{m}$ (Figs 50-53).

Olifantiella pseudobiremis RIAUX-GoBIN sp. nov. (Figs 66-73, SEM)

Features $(\mathrm{n}=6): 6.8-12(9 \pm 2) \mu \mathrm{m}$ long; $1.6-3(2.6 \pm$ 0.6) $\mu \mathrm{m}$ wide

Stria density: $28-38(32.6 \pm 4.5)$ striae in $10 \mu \mathrm{m}$ $\mathrm{L} / \mathrm{W}: 3.5 \pm 0.7$

Descriptio: Frustula isovalvata et biraphidea, solitaria. Valvae naviculiformes, apicibus rotundatis. $6.8-12$ $\mu m$ longae, 1.6-3 $\mu \mathrm{m}$ latae; c. 32.6 striae in $10 \mu \mathrm{m}$, SD 4.5.

Externa structura: valva convexa; uniseriatae striae radiantes ad subparallelae externe per totam longitudinem apertae et granulato hymenio clausae. Foramen transapicaliter oblongum praesens unilateraliter, juxta poros centrales raphis, ad extremitatem striarum duarum centralum. Unus rotundus tholus inter pori centrales positus. Marginalis lata camera, elevata, ad angulum inter limbum et 


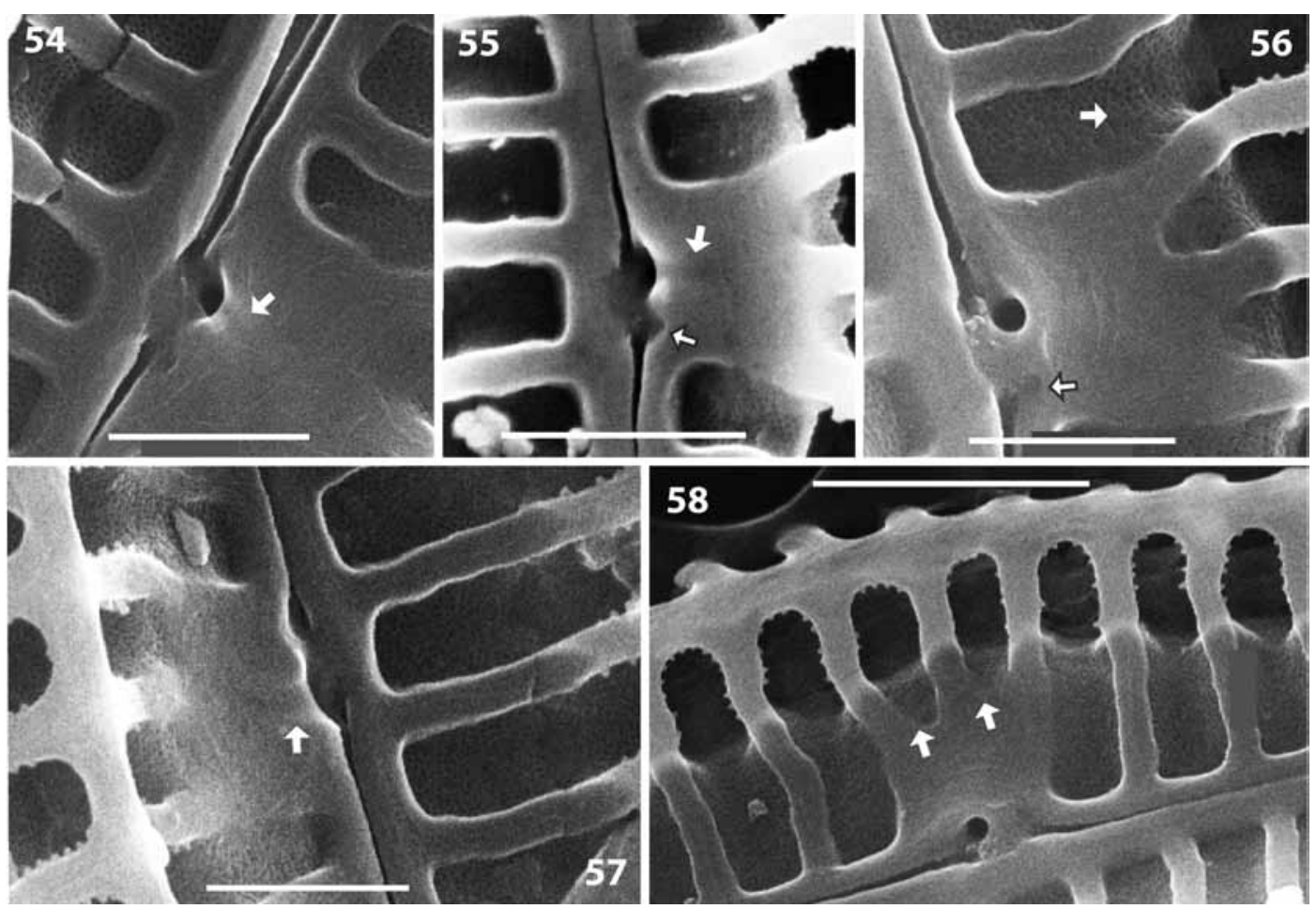

Figs 54-58. Olifantiella paucistriata sp. nov., (SEM): (54-58) round process opening (near one raphe ending) with an internal elongation seen through the valve (Figs 54, 55, 57, white arrows), small depression near the other raphe ending (Figs 55, 56, framed arrows); (58) general view of the central area, with two shortened striae facing the process opening (arrows). Scale bars $1 \mu \mathrm{m}$ (Fig. 58), $0.5 \mu \mathrm{m}$ (Figs 54-57).

frontem posita, cum parvis aperturis. Foramina in apicibus hymenio clausea, cum parvae apertae. Area axialis linearis. Raphe recta; pori centrales approximati, simpliciter dilatati et leniter deflecti ab processus foramine ; pori externi terminales simpliciter dilatati et leniter deflecti.

Interna structura: non observata.

Description: elliptical to oblong frustule (Fig. 66). the striae are composed of large macroareolae covered by finely perforated hymen (Figs 69, 71, 73, white arrows). Presence of several girdle bands with regular rows of puncta (Fig. 67). Terminal raphe endings simple, slightly bent (Fig. 68). Apical slits, in same density as on the mantle, occluded by a velum, with a small opening and spines (Fig. 68, arrow). One process opening, near the central area, transversally elongate, while a round small wart is generally located on the other side of the central area (Figs 69, 70, 73). Two shortened stria present near the valve margin on the side of the external opening of the process (Fig. 71, framed arrow). A lateral ridge forms a real chamber running around the valve, with reinforcements corresponding to each interstria (Figs 66, 68, 72), but no internal transapical septa, as illustrated in a broken frustule (Fig. 72, framed arrows). This chamber has large fenestrae-like structures corresponding to each stria, covered by a granular velum with a coarser structure than that of the macroareola hymenes (Figs 67, 68, 71). Each transapical sector of the chamber, opens externally by two small openings (one near the margin and one on the valve face), ornamented by curved small spines (Fig. 68).

Remarks: the structure of the frustule is more complex than that of Olifantiella generitype, e.g. the lateral ridge being a real chamber occluded by a specific velum. The internal process remains to be examined before a full description of this taxon can be made, nevertheless the oblong and deep process opening seem in favour of the presence of a tubular internal system (Fig. 69, framed arrow).

The morphologic features of Olifantiella pseudobiremis may be compared with that of the genus Biremis, hence the epithet. Nevertheless the simple terminal raphe endings and the presence of an external process opening, differ from the description of Biremis (e.g. Round et al. 1990; SABbe et al. 1995; VyVERMAn et al. 1997; EdLund et al. 2001). Biremis zachariasii (REICHELT) EdLuND, ANDRESEn \& Soninkhishig (EdLund et al. 2001), a freshwater taxon, shows similitude with our 


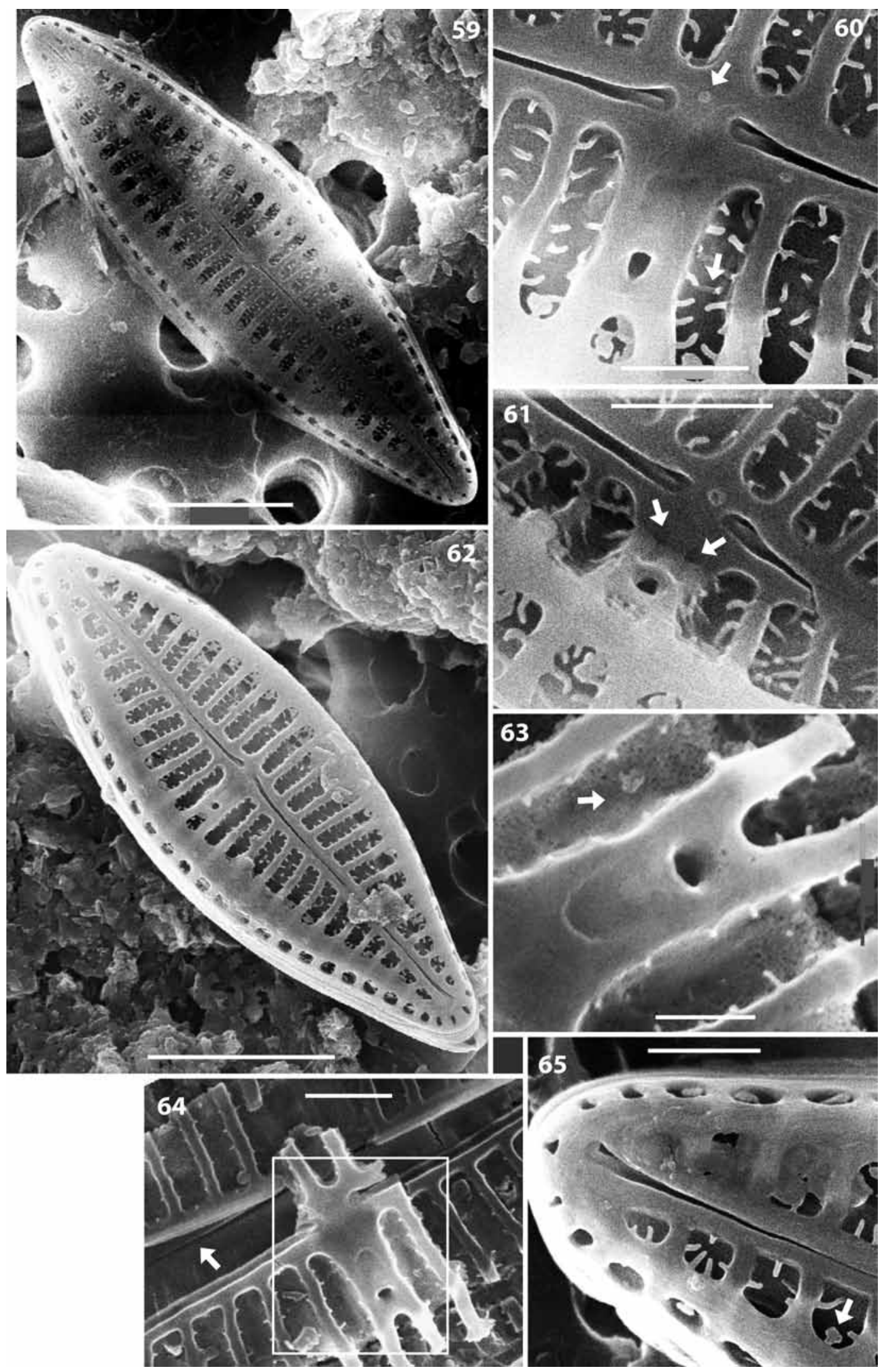

Figs 59-65. Olifantiella pilosella sp. nov., (SEM): $(59,62)$ external views of the frustule (Fig. 62: specimen from Moorea, Pacific); (60-63) process opening shape and position (with two grooves facing the raphe endings, Fig. 61, arrows), long vermicule-like spines on the hymen of the areolae (Fig. 60, arrow), a small wart near the raphe endings (Fig. 60, arrow), and finely perforated hymen (Fig. 63, arrow); (64) broken frustule showing the raphe of the underlying valve (arrow); opening of the process detailed in Fig. 63; (65) terminal raphe ending, and small flat appendix (arrow). Scale bars $2.5 \mu \mathrm{m}$ (Fig. 59), $2 \mu \mathrm{m}$ (Fig. 62), $0.5 \mu \mathrm{m}$ (Figs 60, 61, 64, 65), $0.2 \mu \mathrm{m}$ (Fig. 63). 


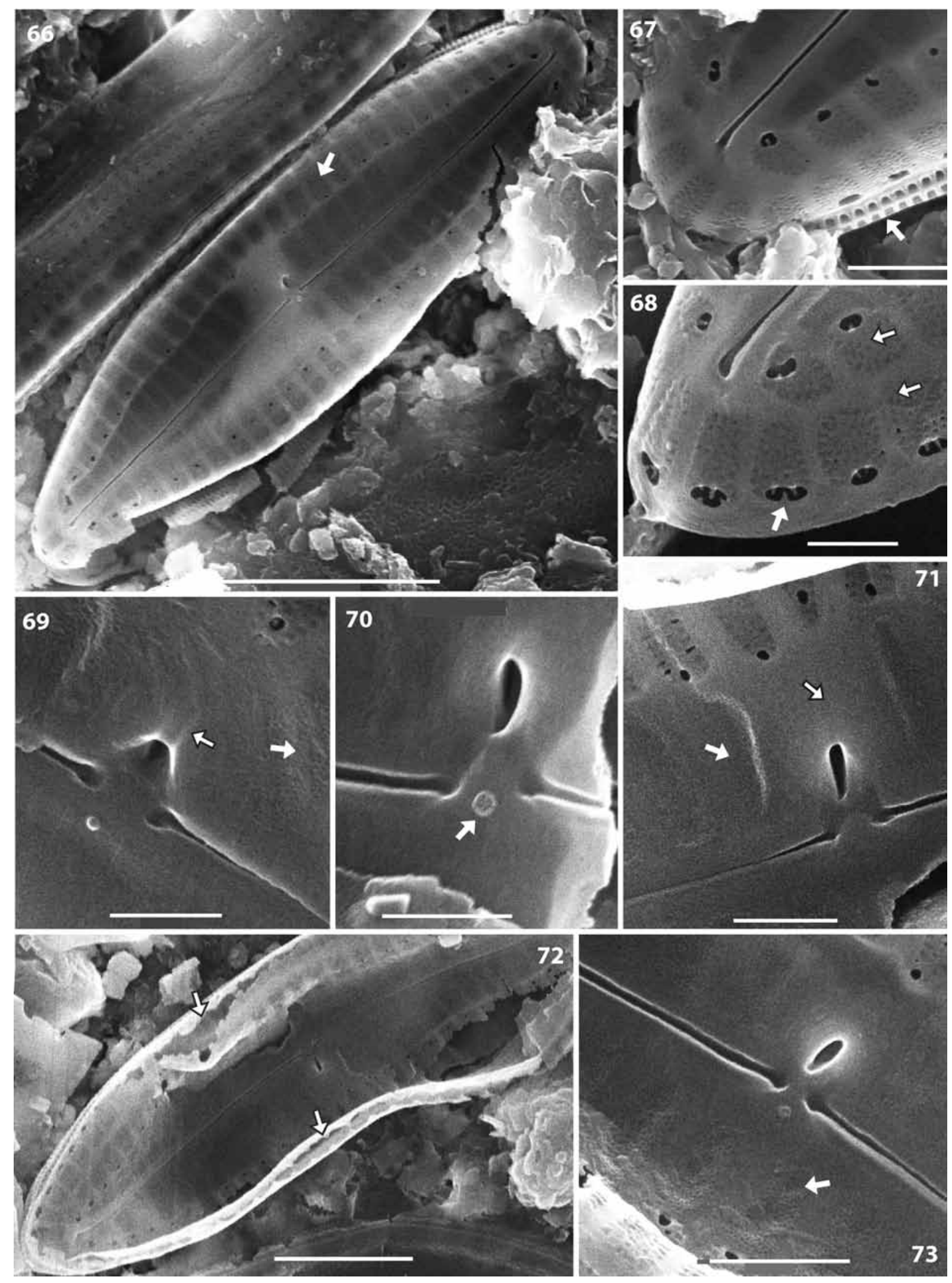

Figs 66-73. Olifantiella pseudobiremis sp. nov., (SEM): (66) entire valve with the marginal chamber (arrow); $(67,68)$ terminal raphe endings, and girdle bands with puncta (Fig. 67, arrow), and small openings with spines (Fig. 68, arrow); (69-71, 73) central area details, process opening with a tubular structure seen throw the frustule (Fig. 69, framed arrow), finely perforated hymen of the macroareolae (Fis 69, 71, 73, arrows), area lacking macroareolae (Fig. 71, framed arrow), small siliceous wart near the raphe endings (Fig. 70, arrow); (72) broken frustule showing absence of septa in the marginal chamber (framed arrows). Scale bars $3 \mu \mathrm{m}$ (Fig. 66), $2 \mu \mathrm{m}$ (Fig. 72), $0.5 \mu \mathrm{m}$ (Figs 67, 71, 73), $0.3 \mu \mathrm{m}$ (Figs 68-70). 
taxon, but here again, the terminal raphe endings "deflect unilaterally in simple, bent endings that terminate at an elongate distal mantle areola", and no internal process is described. Furthermore, if the marginal chamber is internally closed by a "cribral plate" (ibid.), externally the chamber is covered by a continuous silica wall, with two rows of foramina. In our taxon the chamber is occluded by a finely perforated velum, slightly different from that of the valve face macroareolae. In Biremis zachariasii, and in contrast with previous descriptions of Biremis (Round et al. 1990; Vyverman et al. 1997), there are "occluded areolae" along the axial area. But the oblong areolae in Biremis zachariasii, with a depressed hymen, are different from the macroareola hymen in Olifantiella pseudobiremis.

Olifantiella pseudobiremis is also related to Scolotropis CLEVE and Scopliopleura Grunow, with loculate striae, and Progonia Schrader, with complex chambered striae (Round et al. 1990). But the three latter genera have characteristics different from Olifantiella, in particular their terminal raphe slits, central raphe endings and external wall of the chambers.

The simple terminal raphe endings, stria structure and process opening, present in our taxon, fit the characteristics of Olifantiella, justifying its classification in this genus.

Habitat: extremely rare, six specimens observed, so far only found in Rodrigues.

Holotype: stub A (31 10 08) from sample "Port Mathurin 2": Fig. 66, original picture (SEM 311008-12) in Collection C. RiauX-GobIN.

Type locality: Port Mathurin beach (Rodrigues Island).

Isotypes: see Olifantiella rodriguensis (slides BM 101461, ZU7/42, ALH TRO GOT 121, ROD1).

\section{Discussion}

\section{General remarks}

The new taxa are all small-sized, naviculoid to oblong in shape. Apart from Olifantiella cf. mascarenica, which is morphologically similar to the generitype except for the cell symmetry, the other taxa differed from the generitype in: 1) the structure and complexity of their buciniportula: paired/double ( $O$. rodriguensis), to multiple $(O$. gorandiana $), 2)$ the shape and location of the process opening: oblong close to the central area (O. rodriguensis, O. pseudobiremis), round close to the central area (O. paucistriata), tearlike halfway between the central nodule and the valve margin (O. pilosella), or trapezoidal close to the valve face margin $(O$. gorandiana $), 3)$ the presence of long spines or complex ornamentation around the macroareolae, presence of a complex ridge, or sort of marginal chamber (O. pilosella, O. paucistriata, O. pseudobiremis), 4) presence in external view of a siliceous wart close to the central raphe endings (O. paucistriata, O. pseudobiremis). Among the new taxa, O. pseudobiremis has the most sophisticated external structure.

\section{Buciniportula}

The buciniportula, as defined in the generitype, is a tubular simple and raised internal process. In the described new taxa, the internal process is simple or multiple, raised or not, but always composed of tubular structures, and are therefore also called buciniportulae.

The buciniportula is more complex than the simple stigma present in Fistulifera (LangeBERTALOT 1997) or in Labellicula (described as close to the Fistulifera internal process by VAN DE VIJVER et al. 2005). The buciniportula also differs from the narrow slit present in Gomphoneis CLEVE, or the "convoluted spongy bosses of silica" in Didymosphaenia SCHMIDT or Cymbella AgARDH (Round et al. 1990). All the latter structures open externally by a "pore", except for Fistulifera where it opens by an apically elongate fissure, or "fistule", lying between the central raphe endings. In Labellicula, according to VAN DE VIJVER et al. (2005), the "two stigmata" are "irregularly placed" and "externally difficult to find", as in their Fig. 13 (ibid.). Nevertheless, we can note that in Fig. 20 (ibid.) the opening is well identifiable. In Olifantiella, the buciniportula opens by a more or less extended opening always well identifiable in SEM, and with a well defined location in each taxon. The lipped internal slit in Luticola seems to be a closely related structure when compared with the buciniportula, but with an adjoined more or less complex tubular system in Olifantiella.

The external opening of the process, unique in Olifantiella, has a shape in relation with the complexity of the internal structure. The higher complexity is observed in $O$. gorandiana. The multiple buciniportula of $O$. gorandiana may correspond to four modified striae (as suggested in Fig. 18 for O. rodriguensis, where a connection clearly exists between the process opening and a modified stria, Fig. 18, arrow). In the generitype, 
and also in $O$. cf. mascarenica, the simple process corresponds to only one modified stria.

The symmetry of the process seems to vary within taxa (interspecific variation), but also among specimens of the same species (intraspecific variation). More observations are needed to confirm this fact.

The role of the buciniportula is presently unknown. In Figs 32-33 (framed arrows), mucilage(?) or another substance, extrudes from the foramen of two specimens of $O$. gorandiana. No acid or invasive treatment was applied to the samples, allowing observation of the natural connection of cells to the substratum. All described taxa seem to be epipelic since there are never found attached to macroalgae or to coral sand grains (as is often the case for Cocconeis species), but as free cells (e.g. as Navicula taxa). They are rarely observed as paired cells, never in chain. The role of the process remains unclear.

\section{Emended definition of the genus Olifantiella}

Even if more SEM effort is needed before a full description of several rare Olifantiella taxa can be achieved (e.g. internal processes, girdle bands and valvocopulae, which were easier to examine in the generitype due to its relative abundance), a redefinition of the genus can be given:

Olifantiella taxa are small-sized symmetric Biraphidineae with: 1) parallel to slightly radiate striae, opening along their whole length on the outside (e.g. macroareolae), closed by an uninterrupted finely perforated hymen, 2) externally, a ridge, more or less elevated and sophisticated, runs at the periphery of the valve at the junction of the valve face and the mantle and steps over the striae, 3) central raphe endings bent away from the process opening, 4) raphe endings simple and very slightly bent, 5) on both valves, a process opening, unique, with different shape, width and position, 7) when observed, internal process or buciniportula, composed of more or less complex tubular structures, raised or not, ending in a bell-mouth plugged or not, or ending in a sort of fan, 6) multiple girdle bands with two to three rows of puncta occluded by a finely perforated velum; some bands lack puncta, 7) apical slits of various shape and number, internally occluded by a domed velum, 8) internally, a siliceous nodule in between the central raphe endings, 9) slightly raised helictoglossae, 10) externally an occasional small wart in the vicinity of the central nodule, 11) a complex narrow wavy structure resembling a valvocopula (until now only observed in the generitype).

\section{Conclusion}

This study reports on the very fine structures of the genus Olifantiella as observed under the SEM, of specimens collected off Rodrigues, notably: 1) the probable high diversity of this genus (found only in tropical areas), 2) the variable shape and complexity of the external process opening and buciniportulae, the role of which remains unclear and 3 ) the variations linked to the symmetry of the frustule (to be confirmed for each taxon).

We can remark that several of these new taxa are naviculoid in shape and may have been previously misidentified due to their small size. We can also remark that the diatom diversity in the eastern part of the Mascarenes (e.g. in Rodrigues) seems high, with possible endemics (RiauX-Gobin et al., pers. obs.), compared to that of Réunion. Rodrigues and Réunion islands lie only $835 \mathrm{~km}$ away from each other, but with a general oceanographic drift from East to West. The next investigations in the Indian Ocean, such as on Éparses atolls (Scattered Islands) or Madagascar reefs, will complete our survey and give a possible response about a real endemism in the easterly islands or Mascarenes. Nevertheless, our recent findings about Olifantiella pilosella in the South-West Pacific (Moorea, Society Islands) may also imply that all these small-sized taxa were overlooked in the past and may be ubiquitous in coral-reef or tropical environments.

\section{Acknowledgments}

We acknowledge Dimitri GorAnd (C2M, UPVD University of Perpignan Via Domitia) for SEM assistance, PIERRE COMPÈre for amending the Latin diagnoses, RICHARD JORDAN for kindly revising the English and an anonymous reviewer for providing helpful comments. We thank "Naturalia \& Biologia" and the "Centre National de la Recherche Scientifique" (CNRS) for funding diatom SEM studies at the Mascarenes. This research was first presented as a poster at the 28th ADLaF colloquium (Association of French speaking diatomists), held in Banyuls/mer-F in September 2009.

\section{References}

Anonymous (1975): Proposals for a standardization 
of diatom terminology and diagnoses. - Nova Hedwigia Beih 53: 323-354.

BukhtiYarova, L.N. (2006): Additional data on the diatom genus Karayevia and a proposal to reject the genus Kolbesia. - Nova Hedwigia Beih 130: 85-96.

Edlund, M. B.; Andresen, N. A. \& Soninkhishsig, N. (2001): Morphology of Oestrupia zachariasii and its transfer to Biremis. - Diat. Res. 16: 295-306.

Lange-Bertalot, H. (1997): Frankophila, Mayamaea und Fistulifera: drei neue Gattungen der Klasse Bacillariophyceae. - Arch. Protistenkd. 148: 65-76.

McNeil, J.; Barrie, F.R.; Burdet, H.M.; Demoulin, V.; Hawksworth, D.L.; Marhold, K.; Nicolson, D.H.; Prado, J.; Silva, P.C.; Skog, J.E.; Wiersma, J.H. \& TuRLAND, N.J. (2006): International code of botanical nomenclature. Regnum Vegetabile 146, xviii+568 pp.

Riaux-Gobin, C. \& Compère, P. (2009): Olifantiella mascarenica gen. \& sp. nov., a new genus of pennate diatom from Réunion Island, exhibiting a remarkable internal process. - Phycol. Res. 57: $178-185$.

Riaux-Gobin, C.; Witkowski, A.; Saenz-Agudelo, P.; Neveux, J.; Oriol, L. \& Vétion, G. (2011): Nutrients status in coral reefs environment off the Îles Eparses (Scattered Islands): comparison to nearby reefs subject to higher anthropogenic influences (Mozambic Channel and Mascarenes, Indian Ocean). - Oceanol. Hydrobiol. Stud. 40: 84-90.

Ross, R.; Cox, E.J.; Karayeva, N.I.; Mann, D.G.; PAdDOCK, T.B.B.; Simonsen, R. \& Sims, P.A. (1979): An amended terminology for the siliceous components of the diatom cell. - Nova Hedwigia Beih 64: 513-533.

Round, F.E.; Crawford, R.M. \& Mann, D.G. (1990): The Diatoms, Biology and Morphology of the Genera. - 747 pp, Cambridge University Press, Cambridge.

Sabbe, K.; Witkowski, A. \& Vyverman, W. (1995): Taxonomy, morphology and ecology of Biremis lucens comb. nov. (Bacillariophyta): a brackishmarine, benthic diatom species comprising different morphological types. - Bot. Mar. 38: 379-391.

Vyverman, W.; Sabbe, K. \& Vyverman, R. (1997): Five new freshwater species of Biremis (Bacillariophyta) from Tasmania. - Phycologia 36: 91-102.

Van de Vijver, B.; Frenot, Y.; Beyens, L. \& LangeBERTALOT, H. (2005): Labellicula, a new diatom genus (Bacillariophyta) from Île de la Possession (Crozet Archipelago, Subantarctica). - Cryptogamie Algol. 26: 125-133.

(C) Czech Phycological Society (2012)

Received May 23, 2011

Accepted February 29, 2012 